\title{
PENGEMBANGAN RENCANA PELAKSANAAN PEMBELAJARAN METODE JIGSAW MENGGUNAKAN MODUL SAINTIFIK PADA MATERI HUKUM HUKUM DASAR KIMIA DI KELAS X SMA
}

\section{THE DEVELOPMENT OF LEARNING IMPLEMENTATION PLAN JIGSAW METHOD USING THE SCIENTIFIC MODULE ON THE MATERIAL OF BASIC LAW OF CHEMESTRY IN CLASS X SENIOR HIGH SCHOOL}

\author{
ND. Berijaya Tafonao*, Lisa Ariyanti Pohan, Hasrita Lubis \\ Universitas Islam Sumatera Utara, Department of Chemistry Education, Medan, 20217, North Sumatera, \\ Indonesia \\ *Corresponding author: ndtafonao@gmail.com
}

\begin{abstract}
ABSTRAK
Penelitian ini dilakukan berdasarkan analisis kebutuhan yang menunjukan guru masih kesulitan dalam membuat perangkat pembelajaran. Tujuan penelitian ini adalah menghasilkan suatu produk perangkat pembelajaran berupa RPP dan MODUL berbasis saintifik untuk materi hukum hukum dasar kimia siswa kelas X Sekolah Menengah Atas. Penelitian ini menggunakan metode Research and Development (R\&D). Langkahlangkah pengembangan penelitian ini (1) analisis kebutuhan, (2) penelitian dan pengumpulan data, (3) pengembangan produk awal, (4) evaluasi, (5) revisi, (6) penyempurnaan produk akhir. Instrumen yang digunakan dalam penelitian ini adalah angket untuk memvalidasi kualitas perangkat pembelajaran berbasis saintifik oleh pakar pembelajaran dan guru kelas X Sekolah Menengah Atas. Perangkat pembelajaran berbasis saintifik ini dilakukan dengan pengujian atas keterpakain RPP yang dibuat oleh peneliti dan dapat digunakan oleh siswa kelas X serta dikembangkan dengan sangat baik dan layaknya digunakan berdasarkan validasi pakar pembelajaran ahli materi dengan skor $83 \%$ dan pakar media dengan skor $82 \%$. Penilaian perangkat pembelajaran berbasis saintifik sangat layak digunakan berdasarkan validasi guru kelas X dengan skor $85 \%$.
\end{abstract}

Kata Kunci: RPP; Metode Jigsaw; Modul Saintifik; Hukum Hukum Dasar Kimia.

\section{ABSTRACT}

Abstract. This research was conducted based on a needs analysis which showed that teachers still had difficulties in making learning tools. The purpose of this research is to produce a learning device product in the form of lesson plans and scientific-based MODULE for the basic law material of chemistry for class $X$ high school students. This study uses the Research and Development (R\&D) method. The steps of developing this research are (1) needs analysis, (2) research and data collection, (3) initial product development, (4) evaluation, (5) revision, (6) final product refinement. The instrument used in this study was a questionnaire to validate the quality of scientific-based learning tools by learning experts and teachers of class X high school. This scientific-based learning tool is carried out by testing the use of lesson plans made by researchers and can be used by class $X$ students and very well developed and appropriate to use based on the validation of learning experts with material experts with a score of $83 \%$ and media experts with a score of $82 \%$. Assessment of scientific-based learning tools is very feasible to use based on the validation of class X teachers with a score of $85 \%$.

Keywords: RPP; Jigsaw Method; Scientific Module; Basic Law Chemistry. 


\section{PENDAHULUAN}

Ilmu kimia merupakan salah satu rumpun IPA yang ilmunya diperoleh berdasarkan pengamatan terhadap fenomena alam dalam menjawab pertanyaan apa, mengapa dan bagaimana terkait dengan fenomena yang sedang diamati (Suyanti, 2010; Fadiawati, 2014). Hukum kimia adalah teori yang merumuskan fakta-fakta empiris dari berbagai observasi dan eksperimen kimia berulang-ulang menggunakan metode ilmiah. Ada tiga hal yang berkaitan dengan kimia yang tidak terpisahkan, yaitu kimia sebagai produk (pengetahuan kimia yang berupa fakta, konsep, prinsip, hukum, dan teori) temuan ilmuwan dan kimia sebagai proses (kerja ilmiah) dengan menggunakan sikap ilmiah dalam menemukan pengetahuan. Oleh sebab itu, pembelajaran kimia dan penilaian hasil belajar kimia harus memperhatikan karakteristik ilmu kimia sebagai proses, produk, dan sikap (Fadiawati, 2011).

Menurut Putri (2015), mengemukakan bahwa permasalahan pendidikan dalam proses pembelajaran adalah pengajar mentransfer ilmu pengetahuannya dengan menggunakan metode ceramah. Pengajar hanya menyajikan materi secara teoritik dan membahas soal-soal ketika proses kegiatan belajar mengajar berlangsung, adapun penggunaan perangkat pembelajaran dan bahan ajar yang kurang tepat. Peserta didik mengalami kesulitan dalam memahami konsep karena pembelajaran kimia cenderung lebih ke ranah menghafal rumus-rumus kemudian diaplikasikan dengan penerapan soal-soal latihan. Akibat dari kebiasaan tersebut peserta didik menjadi kurang kreatif dalam memecahkan masalah, motivasi belajar siswa rendah, serta kegiatan belajar mengajar kurang efisien dan pada akhirnya prestasi belajar menjadi rendah.

Hal ini diperkuat penelitian Ashadi (2009), yang menyatakan bahwa kesulitan belajar siswa sekolah menengah atas dalam memahami materi pelajaran kimia diperlukan berbagai kriteria batas, sehingga adanya kriteria ini ditetapkan batas dimana siswa dapat diperkirakan mengalami kesulitan pada saat belajar.

Pengajar memiliki beberapa kesulitan dalam melaksanakan kurikulum 2013. Kesulitan-kesulitan tersebut adalah kurangnya pemahaman tujuan kurikulum 2013 dan penggunaan pendekatan saintifik dalam pembelajaran, penggunaan bahasa dalam buku teks yang sulit dipahami serta rendahnya kemampuan pengajar dalam proses pembelajaran yang dapat menumbuhkan kreatifitas siswa dan aplikatif (Krisdiana dkk, 2015).

Lie (2004:41) menyatakan jigsaw didesain untuk meningkatkan rasa tanggung jawab siswa terhadap pembelajarannya sendiri dan juga pembelajaran orang lain. Siswa tidak hanya mempelajari materi yang diberikan, tetapi mereka juga harus siap memberikan dan mengajarkan materi tersebut pada anggota kelompoknya yang lain. Dengan demikian, siswa saling tergantung satu dengan yang lain dan harus bekerja sama secara kooperatif untuk mempelajari materi yang ditugaskan. Para anggota dari tim yang berbeda dengan topik yang sama bertemu untuk diskusi (tim ahli) saling membantu satu sama lain tentang topik pembelajaran yang ditugaskan kepada mereka. Kemudian siswa-siswa itu kembali pada tim/kelompok asal untuk menjelaskan kepada anggota kelompok yang lain tentang apa yang telah mereka pelajari sebelumnya pada pertemuan tim ahli. Pada model pembelajaran kooperatif tipe jigsaw, terdapat kelompok asal dan kelompok ahli. Kelompok asal, yaitu kelompok induk siswa yang beranggotakan siswa dengan kemampuan, jenis kelamin dan latar belakang keluarga yang beragam. Kelompok ahli, yaitu kelompok siswa yang terdiri dari anggota kelompok asal yang berbeda ditugaskan untuk mempelajari dan mendalami topik tertentu dan menyelesaikan tugas-tugas yang berhubungan dengan topiknya untuk kemudian dijelaskan kepada anggota kelompok asal. Kelompok ahli merupakan gabungan dari beberapa ahli yang berasal dari kelompok asal. Kunci keberhasilan jigsaw adalah saling ketergantungan, yaitu setiap siswa bergantung kepada anggota timnya untuk dapat memberikan informasi yang diperlukan supaya dapat berkinerja baik pada saat penilaian (Slavin, 2008:237).

Rencana Pelaksanaan Pembelajaran (RPP) adalah rencana yang menggambarkan prosedur dan pengorganisasian pembelajaran untuk mencapai satu kompetensi dasar. RPP paling luas mencakup satu kompetensi dasar yang meliputi satu atau beberapa indikator untuk sekali pertemuan atau lebih. Salah satu pengembangan Rencana Pelaksanaan Pembelajaran (RPP) dengan kooperatif learning metode Jigsaw 
yaitu Hukum-hukum Dasar Kimia misalnya Hukum Lavoiser (Hukum Kekekalan Massa), Hukum Proust (Hukum Perbandingan Tetap), dan Hukum Dalton (Hukum Kelipatan Berganda). Penerapan model kooperatif learning dengan pendekatan Jigsaw diharapkan agar siswa lebih antusias dan belajar dengan teman sebaya secara berkelompok untuk mendiskusikan materi yang sedang dipelajari.

Guru yang berkualitas akan selalu menyusun suatu perencanaan untuk proses pembelajarannya, sehingga tidak ada alasan guru ketika mengajar di kelas tanpa perencanaan pembelajaran (Suparmi dkk, 2012). Salah satu aspek dalam perencanaan pembelajaran yaitu guru menyusun suatu perangkat pembelajaran yang akan digunakan selama proses pembelajarannya (Mulyasa, 2011: 21).

Pembelajaran kimia disekolah dapat dikaitkan dengan lingkungan di sekitar agar peserta didik terbiasa menyelesaikan masalah dikehidupan sehari-hari. Pendekatan yang dapat menghubungkan pembelajaran kimia dengan kehidupan sehari-hari khususnya pada materi hukum-hukum dasar kimia dan dapat melatih keterampilan berpikir kritis siswa adalah melalui pendekatan saintifik.

Pendekatan ilmiah atau pendekatan saintifik merupakan pendekatan pembelajaran yang mengkondisikan siswa aktif terlibat dalam proses pembelajaran melalui proses ilmiah, sehingga pengetahuan yang diperoleh siswa merupakan hasil konstruksi siswa sendiri dan diharapkan dapat mengembangkan kemampuan berpikir kritis siswa (Bybee, 2006).

Modul digunakan oleh guru sebagai salah satu sumber belajar yang dijadikan media pembelajaran. Media belajar merupakan informasi, alat, dan teks, yang diperlakukan guru untuk perencanaan dan penelaahan implementasi pembelajaran (Hosnan, $2014: 34$ ).

\section{METODE PENELITIAN}

Metode yang digunakan dalam penelitian ini adalah Research and Development (R\&D) dengan model ADDIE yang terdiri dari lima tahap yaitu Analysis (Analisis), Design (Perancangan), Development (Pengembangan), Implementation (Implementasi) dan Evaluation (Evaluasi) dikembangkan oleh Dick and Carry (1996). Pengembangan model ADDIE ini sering digunakan dalam penelitian dan pengembangan bahan ajar seperti modul, LKS, RPP dan buku ajar. Berdasarkan tahap pengembangan model ADDIE yang dijelaskan oleh Endang Mulyaningsih (2012).

$$
\text { Persentase Kelayakan }=\frac{\text { Jumlah skor yang diperoleh }}{\text { Skor maksimum }} \times 100 \%
$$

\section{HASIL DAN PEMBAHASAN}

\subsection{Penilaian Perangkat Pembelajaran}

\section{a. Uji Kelayakan RPP Oleh Guru Kimia}

Uji kelayakan RPP oleh guru kimia bertujuan untuk mengetahui kelayakan materi dan kesesuaian RPP dengan silabus. Uji kelayakan dilakukan oleh 2 orang guru kimia yaitu Bapak M. Arief Pratama Sam S.Pd. (guru kimia SMA PAB 4 SAMPALI) dan Ibu Sri Wahyuni Lubis S.Si (guru kimia SMA NEGERI 13 Medan). Guru kimia menilai RPP yang dikembangkan oleh peneliti dengan pengisian angket khusus untuk guru kimia. Angket tersebut terdiri dari 18 butir pernyataan yang terbagi menjadi 6 aspek penilaian adapun aspek, identitas mata pelajaran (4 butir pernyataan), rumusan indikator dan tujuan pembelajaran (1 butir pernyataan), pemilihan materi ( 2 butir pernyataan), kegiatan pembelajaran dengan pendekatan saintifik ( 8 butir pernyataan), pemilihan media/sumber belajar ( 1 butir pernyataan) dan penilaian hasil belajar ( 2 butir pernyataan). 
Tabel 1. Kelayakan RPP Oleh Guru Kimia

\begin{tabular}{|c|c|c|c|c|c|c|c|}
\hline \multirow{2}{*}{ Aspek } & \multicolumn{2}{|c|}{ Nilai } & \multirow{2}{*}{ Item } & \multirow{2}{*}{$\begin{array}{l}\text { Skor } \\
\text { Total }\end{array}$} & \multirow{2}{*}{ F.H } & \multirow{2}{*}{$\%$} & \multirow{2}{*}{ Keterangan } \\
\hline & G.Km 1 & G.Km 2 & & & & & \\
\hline Identitas RPP & 18 & 17 & 4 & 35 & 40 & 87 & S. layak \\
\hline Rumusan Indikator & 4 & 4 & 1 & 8 & 10 & 80 & Layak \\
\hline Pemilihan Materi & 8 & 9 & 2 & 17 & 20 & 85 & S. Layak \\
\hline Kegiatan saintifik & 36 & 36 & 8 & 72 & 80 & 90 & S. Layak \\
\hline Memilih Media & 4 & 4 & 1 & 8 & 10 & 80 & Layak \\
\hline \multirow[t]{3}{*}{ Hasil Belajar } & 8 & 9 & 2 & 17 & 20 & 85 & S. Layak \\
\hline & & & & \multicolumn{2}{|c|}{ Jumlah } & 507 & S. Layak \\
\hline & & & & \multicolumn{2}{|c|}{ Rata-rata } & 85 & \\
\hline
\end{tabular}

Hasil yang diperoleh dari perhitungan pada tabel 1 memperlihatkan bahwa dari guru kimia, RPP berbasis saintifik secara keseluruhan tergolong "sangat layak" dengan hasil rata-rata kelayakan " $85 \%$ ".

Adapun nilai kelayakan pada masing-masing aspek adalah aspek identitas RPP berjumlah 87\% dengan kategori sangat layak, aspek rumusan indikator berjumlah $80 \%$ dengan kategori layak, aspek pemilihan materi berjumlah $85 \%$ dengan kategori layak, aspek kegiatan saintifik $90 \%$ dengan kategori sangat layak, aspek memilih media berjumlah $80 \%$ dengan kategori layak dan aspek hasil belajar berjumlah $85 \%$ dengan kategori layak.

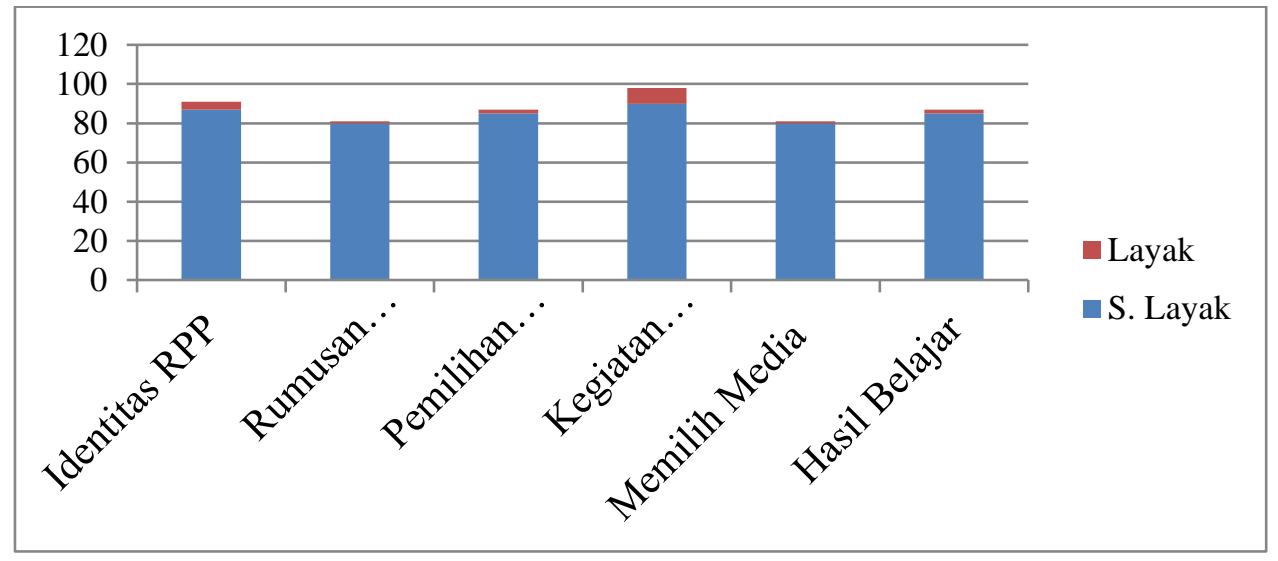

Gambar 1. Grafik persenan kelayakan RPP dari aspek guru kimia

\section{b. Uji Kelayakan Modul Oleh Ahli Materi}

Uji kelayakan modul pembelajaran oleh ahli materi bertujuan untuk mengetahui kelayakan dan kesesuaian materi dengan silabus. Uji kelayakan ini dilakukan oleh 2 orang ahli materi yaitu Bapak M. Arief Pratama Sam S.Pd. (guru kimia SMA PAB 4 SAMPALI) dan Sri Wahyuni Lubis S.Si (guru kimia SMA NEGERI 13 Medan). Ahli materi menilai modul pembelajaran yang dikembangkan oleh peneliti dengan pengisian angket khusus untuk ahli materi. Angket tersebut terdiri dari 16 butir pernyataan yang terbagi menjadi 4 aspek penilaian sebagai berikut, aspek kelayakan isi ( 5 butir pernyataan), aspek kebahasaan (3 butir pernyataan), aspek sajian ( 5 butir pernyataan), dan aspek kegrafikan (3 butir pernyataan). 
Tabel 2. Modul aspek materi

\begin{tabular}{|c|c|c|c|c|c|c|c|}
\hline \multirow{2}{*}{ Aspek } & \multicolumn{2}{|c|}{ Nilai } & \multirow[t]{2}{*}{ Item } & \multirow{2}{*}{$\begin{array}{l}\text { Skor } \\
\text { Total }\end{array}$} & \multirow{2}{*}{ F.H } & \multirow{2}{*}{$\%$} & \multirow{2}{*}{ Keterangan } \\
\hline & A.Man & A.Man & & & & & \\
\hline Kelayakan isi & 22 & 21 & 5 & 43 & 50 & 86 & S. Layak \\
\hline $\begin{array}{l}\text { Penilaian } \\
\text { bahasa }\end{array}$ & 12 & 13 & 3 & 25 & 30 & 83 & S. Layak \\
\hline $\begin{array}{l}\text { Aspek } \\
\text { Penyajian }\end{array}$ & 21 & 21 & 5 & 42 & 50 & 84 & S. Layak \\
\hline \multirow[t]{2}{*}{$\begin{array}{l}\text { Penilaian } \\
\text { kegrafikaan }\end{array}$} & 13 & 12 & 3 & 25 & 30 & 80 & Layak \\
\hline & & & & \multicolumn{2}{|c|}{ Jumlah } & $\frac{333}{83}$ & S. Layak \\
\hline
\end{tabular}

Hasil yang diperoleh dari perhitungan pada tabel 2 memperlihatkan bahwa dari aspek materi, modul berbasis saintifik secara keseluruhan tergolong "layak" dengan hasil rata-rata kelayakan "83\%".

Adapun nilai kelayakan pada masing-masing aspek adalah aspek kelayakan isi berjumlah $86 \%$ dengan kategori sangat layak, aspek penilaian bahasa berjumlah 83\% dengan kategori sangat layak, aspek penyajian berjumlah $84 \%$ dengan kategori sangat layak dan aspek penilaian kegrafikan berjumlah $80 \%$ dengan kategori layak.

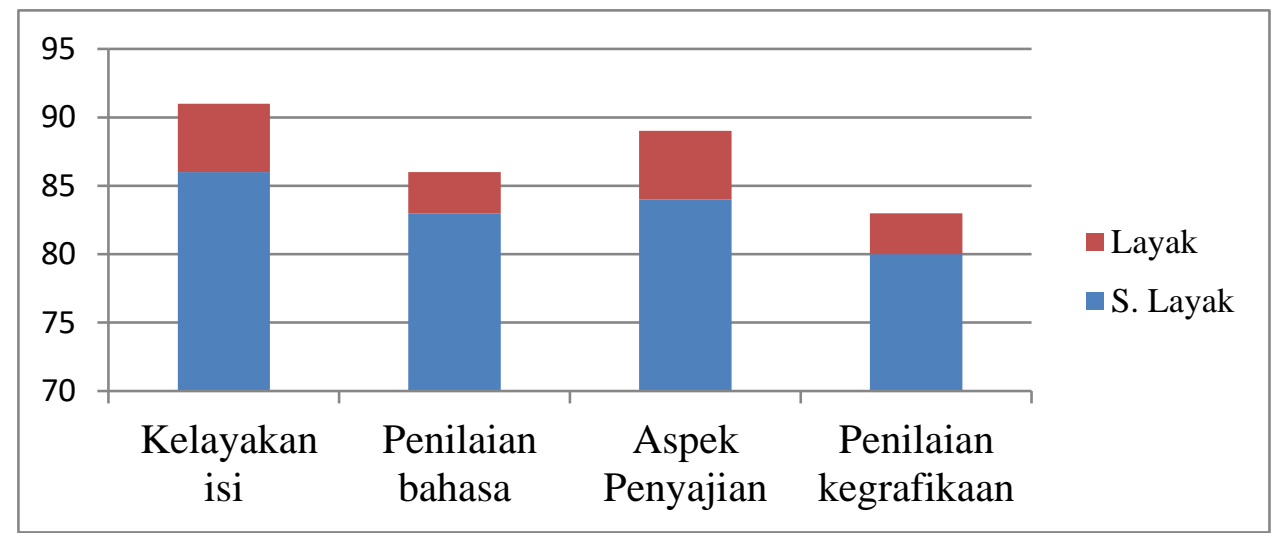

Gambar 2. Grafik persenan kelayakan modul dari aspek materi

\section{c. Uji Kelayakan Modul Oleh Ahli Media}

Uji kelayakan modul pembelajaran oleh ahli media bertujuan untuk mengetahui kelayakan dari segi media pembelajaran. Uji kelayakan ini dilakukan oleh 2 orang ahli media yaitu ibu Adilah Wirdhani Lubis, S.Pd.,M.Si (dosen pendidikan kimia UISU ) dan ibu Wilda wani Siregar, S.Pd.,M.Pd (dosen pendidikan kimia UISU). Ahli media menilai modul pembelajaran yang dikembangkan oleh peneliti dengan pengisian angket khusus untuk ahli media. Angket tersebut terdiri dari 16 butir pernyataan yang terbagi menjadi 6 aspek penilaian sebagai berikut, aspek tampilan desain layar (3 butir pernyataan), aspek kemudahan penggunaan ( 3 butir pernyataan), aspek konsistensi ( 3 butir pernyataan), aspek penilaian format ( 2 butir pernyataan), aspek kemanfaatan ( 2 butir pernyataan) dan aspek kegrafikan (3 butir pernyataan). 
Tabel 3. Modul aspek media

\begin{tabular}{|c|c|c|c|c|c|c|c|}
\hline \multirow{2}{*}{ Aspek } & \multicolumn{2}{|r|}{ Nilai } & \multirow[t]{2}{*}{ Item } & \multirow{2}{*}{$\begin{array}{l}\text { Skor } \\
\text { Total } \\
\end{array}$} & \multirow[t]{2}{*}{ F.H } & \multirow[t]{2}{*}{$\%$} & \multirow[t]{2}{*}{ Keterangan } \\
\hline & A.Me 1 & $\mathrm{~A} . \mathrm{Me}_{2}$ & & & & & \\
\hline $\begin{array}{ll}\text { Aspek } & \text { Tampilan } \\
\text { Desain } & \end{array}$ & 13 & 13 & 3 & 26 & 30 & 86 & S. layak \\
\hline $\begin{array}{l}\text { Kemudahan } \\
\text { Penggunaan }\end{array}$ & 12 & 13 & 3 & 25 & 30 & 83 & S. Layak \\
\hline $\begin{array}{l}\text { Penilaian } \\
\text { Konsistensi }\end{array}$ & 13 & 12 & 3 & 25 & 30 & 83 & S. Layak \\
\hline $\begin{array}{l}\text { Aspek Penilaian } \\
\text { Format }\end{array}$ & 9 & 8 & 2 & 17 & 20 & 85 & S. layak \\
\hline $\begin{array}{l}\text { Penilaian } \\
\text { Kemanfaatan }\end{array}$ & 8 & 8 & 2 & 16 & 20 & 80 & Layak \\
\hline \multirow[t]{3}{*}{ Aspek Kegrafikan } & 12 & 12 & 3 & 24 & 30 & 80 & Layak \\
\hline & & & & \multicolumn{2}{|c|}{ Jumlah } & 497 & \multirow{2}{*}{ S. layak } \\
\hline & & & & ta & & 82 & \\
\hline
\end{tabular}

Hasil yang diperoleh dari perhitungan pada tabel 3 memperlihatkan bahwa dari aspek media, modul berbasis saintifik secara keseluruhan tergolong "sangat layak" dengan hasil rata-rata kelayakan "82\%".

Adapun nilai kelayakan pada masing-masing aspek adalah aspek tampilan desain berjumlah $86 \%$ dengan kategori sangat layak, aspek kemuahan penggunakan berjumlah 83\% dengan kategori sangat layak, aspek penilaian konsistensi berjumlah $83 \%$ dengan kategori sangat layak, aspek penilaian format berjumlah $80 \%$ dengan kategori layak, aspek penilaian kemanfaatan berjumlah $80 \%$ dengan kategori layak dan aspek penilaian kegrafikan berjumlah 90\% dengan kategori sangat layak.

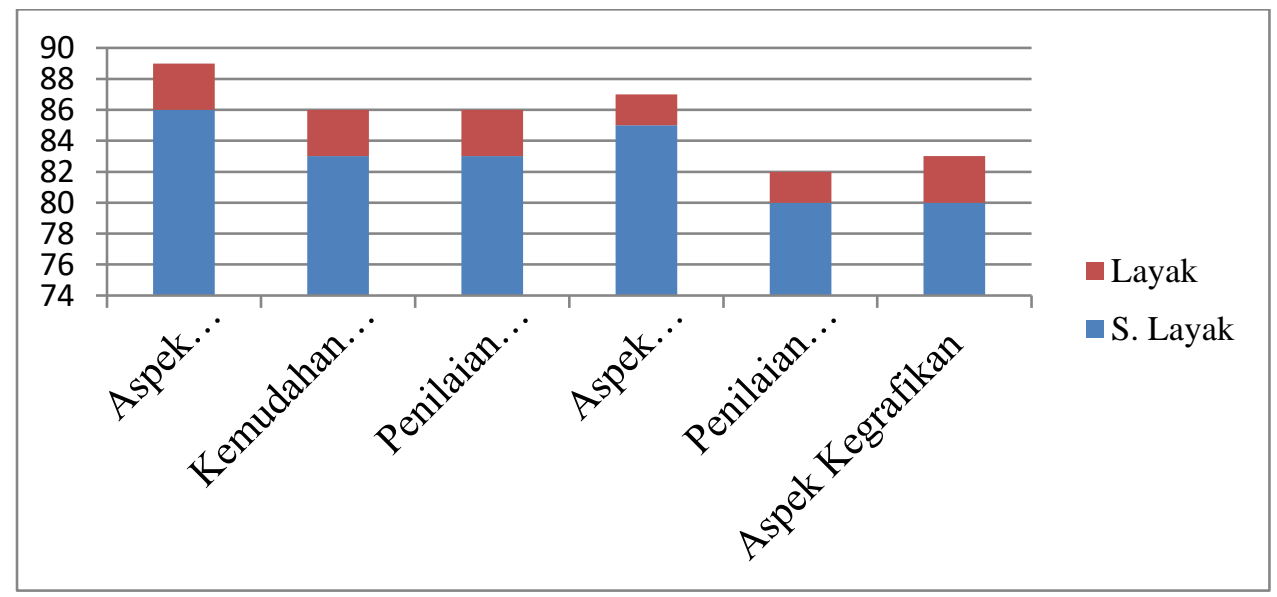

Gambar 3. Grafik persenan kelayakan modul dari aspek media 


\section{d. Aspek Angket Respon Siswa}

Berikut ini presentase dari masing-masing respon peserta didik terhadap modul elektronik pada materi sifat koligatif larutan terdidri dari 10 peserta didik.

Tabel 4. Hasil Angket Respon Siswa

\begin{tabular}{|c|c|c|c|c|c|c|c|c|c|c|c|}
\hline \multirow{3}{*}{ No } & \multirow{3}{*}{ Pertanyaan } & \multirow{2}{*}{\multicolumn{5}{|c|}{ Jumlah Peserta }} & \multirow{2}{*}{\multicolumn{5}{|c|}{$\begin{array}{c}\text { Presentase } \\
\%\end{array}$}} \\
\hline & & & & & & & & & & & \\
\hline & & SS & $S$ & CS & $\mathrm{KS}$ & STS & SS & $\mathrm{S}$ & $\mathrm{CS}$ & KS & STS \\
\hline 1 & Pembelajaran dengan modul membuat saya semangat dalam belajar & 2 & 2 & 1 & & & 40 & 40 & 20 & & \\
\hline 2 & $\begin{array}{l}\text { Kegiatan pembelajaran kimia yang telah dilaksanakan membantu saya } \\
\text { lebih mudah memahami masalah ketika belajar kimia. }\end{array}$ & 2 & 3 & & & & 40 & 60 & & & \\
\hline 3 & $\begin{array}{l}\text { Saya dapat memperoleh pengetahuan baru dengan mengikuti serangkaian } \\
\text { kegiatan dalam modul. }\end{array}$ & 1 & 3 & 1 & & & 20 & 60 & 20 & & \\
\hline 4 & $\begin{array}{l}\text { Saya yakin dapat memahami seluruhisi } \\
\text { modul ini dengan baik. }\end{array}$ & 2 & 2 & 1 & & & 40 & 40 & 20 & & \\
\hline 5 & $\begin{array}{l}\text { Saya menggunakan pengalaman yang saya peroleh untuk mengerjakan } \\
\text { soal-soal pada modul. }\end{array}$ & 2 & 3 & & & & 40 & 60 & & & \\
\hline 6 & $\begin{array}{l}\text { Pembelajaran ini membuat saya senang berdiskusi dengan anggota } \\
\text { kelompok untuk menyelesaikan masalah dengan saling bertukar hasil } \\
\text { jawaban. }\end{array}$ & 3 & 1 & 1 & & & 60 & 20 & 20 & & \\
\hline 7 & Saya selalu memeriksa kembali hasil pekerjaan saya. & 2 & 3 & & & & 40 & 60 & & & \\
\hline 8 & $\begin{array}{l}\text { dengan pembelajaran ini saya sering memodelkan soal dengan } \\
\text { menggunakan gambar atau sketsa. }\end{array}$ & 1 & 4 & & & & 20 & 80 & & & \\
\hline 9 & $\begin{array}{l}\text { Kegiatan siswa dan soal latihan dalam modul membantu saya untuk } \\
\text { mengembangkan kemampuan kimia saya }\end{array}$ & 2 & 3 & & & & 40 & 60 & & & \\
\hline 10 & $\begin{array}{l}\text { Dari setiap kegiatan yang ada dalam modul ini, saya dapat menyimpulkan } \\
\text { dan mengambil ide-ide penting mengenai materi Hukum Hukum Dasar } \\
\text { Kimia. }\end{array}$ & 3 & 2 & & & & 60 & 40 & & & \\
\hline \multicolumn{2}{|r|}{ jumlah $\%$} & & & & & & 400 & 520 & 80 & & \\
\hline \multicolumn{2}{|c|}{ presentase sangat setuju (ss) } & & & & & & & & $40 \%$ & & \\
\hline \multicolumn{2}{|c|}{ presentase setuju (s) } & & & & & & & & $52 \%$ & & \\
\hline \multicolumn{2}{|c|}{ presentase cukup setuju (cs) } & & & & & & & & $8 \%$ & & \\
\hline
\end{tabular}

\subsection{Pembahasan}

Setelah dalam penelitian ini dilakukan perhitungan data yang sudah diperoleh bahwa nilai ratarata kelayakan RPP berbasis Saintifik berdasarkan nilai yang diperoleh dari guru kimia sebesar 89\% dengan kategori sangat layak.

Begitu pula dengan penilaian kelayakan Modul Hukum Hukum Dasar Kimia yang sudah diperoleh dari ahli materi sebesar 85\% dengan kategori layak dan penilaian dari ahli media sebesar 83\% dengan kategori sangat layak sehingga dapat diketahui rata-rata kelayakan modul secara keseluruhan memiliki persentasi 82\% dengan kategori sangat layak. Sehingga RPP dan Modul Pembelajaran Hukum Hukum Dasar Kimia berbasis Saintifik dapat dipergunakan bagi sekolah khususnya sekolah yang menjadi sasaran peneliti.

Hasil uji kelayakan yang dilakukan oleh guru kimia, ahli materi, dan ahli media kemudian dilakukannya revisi oleh peneliti guna untuk memperbaiki RPP dan Modul Pembelajaran Hukum Hukum Dasar Kimia berbasis Saintifik sehingga layak digunakan pada proses belajar mengajar kimia khususnya pada materi hukum hukum dasar kimia kelas X. Revisi RPP dan Modul Pembelajaran Hukum Hukum Dasar Kimia Berbasis Saintifik berdasarkan komentar, saran dan penilaian para guru kimia, ahli materi, dan ahli media.

Penelitian pengembangan perangkat pembelajaran terpadu berbasis Saintifik yang mencakup kepada K13. Merupakan hal yang baru sehingga sedikit yang dapat digunakan sebagai sumber penelitian penelitian pengembangan perangkat pembelajaran.

Sesuai dengan yang diungkapkan Nurdin (2016), bahwa sistem pembelajaran Modul dipandang lebih efektif karena pembelajaran Modul merupakan salah satu bentuk pembelajaran mandiri yang dapat 
membimbing siswa untuk belajar sendiri terhadap materi pembelajaran tanpa adanya campur tangan guru ataupun dosen.

Dalam pelaksanaan pembelajaran, guru menjelaskan tujuan pembelajaran dan membentuk kelompok ahli serta meminta kelompok ahli kembali kekelompok asal dan mempersilahkan kelompok ahli tersebut melakukan presentasi.

Adapun komentar dan saran dari ahli materi yaitu : (1) Materi dalam modul sudah sesuai dengan $\mathrm{KD}, \mathrm{KI}$, dan indikator hanya saja perlu keruntutan materi antara materi hukum hukum dasar kimia dengan contoh; (2) penulisan soal evaluasi dibuat runtut sesuai dengan urutan materi hukum hukum dasar kimia; (3) hendaknya menggunakan bahasa baku penulisan buku. Sedangkan pada ahli media yaitu : (1) penggunaan simbol yang masih kurang rapi; (2) kesalahan pengetikan yang harus dibenahi; (3) penggunaan spasi yang tidak konsisten.

Berdasarkan komentar dan saran dari ahli materi, sebelumnya soal evaluasi dan contoh ditulis tidak runtut sesuai urutan materi hukum hukum dasar kimia. Kemudian dilakukan perbaikan menjadi runtut agar peserta didik lebih mudah mempelajari dan menjawab soal-soal yang tertera. Sedangkan berdasarkan komentar dan saran dari ahli media, sebelumnya penggunaan simbol dan spasi yang kurang rapi. Kemudian dilakukan perbaikan sehingga tampilan Modul menjadi lebih menarik minat peserta didik untuk belajar.

Penelitian-penelitian diatas yang dilakukan oleh peneliti yaitu tentang pengembangan perangkat pembelajaran berbasis saintifik. Ketiga peneliti diatas dijadikan acuan dalam menyusuan penelitian yang berjudul "Pengembangan Rencana Pelaksanaan Pembelajaran Metode Jigsaw Menggunakan Modul Saintifik Pada Materi Hukum Hukum Dasar Kimia".

\section{Hasil Respon Peserta Didik Terhadap Modul}

Respon peserta didik terhadap modul dapat dilihat pada tabel 4 yang diperoleh penulis dari hasil pengisian angket yang dilakukan siswa. Instrumen angket respon peserta didik dibuat dalam bentuk 10 pertanyaan dan 5 orang peserta didik khususnya kelas X IPA PAB 4 Sampali yang menjadi sampel.

Berdasarkan dari hasil angket respon peserta didik terhadap modul berbasis saintifik pada materi hukum-hukum dasar kimia. Dapat dilihat prestasense sangat setuju memperoleh $40 \%$, presentase setuju memperoleh $52 \%$ dan presentase cukup setuju memperoleh $8 \%$ dari hasil angket respon peserta didik mendapatkan skor rata-rata sebesar $92 \%$ dan berada dalam kategori sangat baik.

\subsection{Simpulan}

\section{SIMPULAN DAN SARAN}

Berdasarkan hasil dan pembahasan dalam penelitian pengembangan ini, maka dapat ditarik kesimpulan sebagai berikut :

1. Pendekatan scientific dalam proses pembelajaran pada kurikulum 2013 yang dipaparkan oleh Hosnan (2014, hal:37) untuk semua jenjang dilaksanakan dengan menggunakan pendekatan scientifik, meliputi menggali informasi melalui pengamatan, bertanya, percobaan dan mengolah data atau informasi, dilanjutkan dengan menganalisis, menalar, kemudian menyimpulkan dan mencipta serta membentuk jejaring.

2. Format utama pembuatan Modul meliputi : (1) judul, (2) kata pengantar, (3) pendahuluan, (4) daftar isi, (5) Tujuan pembelajaran, (6) standar kompetensi, (7) Glosarium, (8) Kegiatan pembelajaran, (9) materi pokok, (10) ringkasan, (11) latihan atau tugas, (12) tes mandiri, (13) post tes, (14) kunci jawaban (15) penutup (16) daftar pustaka.

3. Penelitian ini menghasilkan produk berupa RPP Jigsaw dan Modul Saintifik Pembelajaran Hukum Hukum Dasar Kimia dan Silabus yang berlaku disekolah sesuai dengan standar Depdiknas.

4. Berdasarkan penilaian yang diperoleh secara keseluruhan RPP Jigsaw berbasis Saintifik tergolong sangat layak dengan rata-rata nilai kelayakan mencapai $85 \%$.

5. Modul pembelajaran berbasis saintifik yang diperoleh secara keseluruhan tergolong sangat layak dengan rata-rata nilai kelayakan ahli materi $83 \%$, dan ahli media $82 \%$. 


\subsection{Saran} berikut :

Berdasarakan penelitian pengembangan ini, maka saran yang dapat peneliti berikan sebagai

1. Perangkat pembelajaran yang dikembangkan sebaiknya tidak hanya satu RPP sehingga lebih mengembangkan Silabus.

2. RPP jigsaw berbasis modul Saintifik sebaiknya digunakan oleh seluruh pengampu mata pelajaran khususnya guru kimia sebagai masukan perangkat pembelajaran materi Hukum Hukum Dasar Kimia dalam hal strategi pembelajaran.

3. Modul pembelajaran berbasis Saintifik sebaiknya digunakan oleh seluruh pengampu mata pelajaran khususnya kimia kelas X SMA/MA sebagai masukan bahan ajar pada materi Hukum Hukum Dasar Kimia hal meningkatkan kinerja guru.

4. Bagi peneliti selanjutnya, dapat melakukan validasi pengembangan RPP dan Modul Pembelajaran Berbasis Saintifik sampai pada tahap validasi evaluasi penilaian respon siswa.

\section{DAFTAR PUSTAKA}

Ashadi.(2009). Kesulitan Belajar Kimia bagi Siswa Sekolah Menengah Atas.Jakarta: PT. Rineka Cipta. Bybee, R.W. (2006). Scientific Inquiry and Nature of Science. Netherlands: Springer.

Fadiawati, N. (2011). Perkembangan Konsepsi Pembelajar Tentang Struktur Atom dari SMA Hingga Perguruan Tinggi.Disertasi. Bandung: Universitas pendidikan Indonesia.

Fadiawati, N. (2014). Ilmu Kimia sebagai Wahana Mengembangkan Sikap dan Keterampilan Berpikir. Eduspot Edisi 10 (Maret-Juni), hlm 8-9.

Hosnan, 2014.Pendekatan Saintifik Dan Kontekstual Dalam Pembelajaran Abad 21 Kunci Sukses Implementasi Ku-rikulum 2013. Bogor: Ghalia Indonesia.

Krisdiana,dkk. 2015. Analisis Pengaruh Kepuasan Kerja dan Motivasi Terhadap Kinerja Karyawan Dengan Komitmen Organisasional Sebagai Variabel Intervening. Jurnal Ekonomi Managemen Diponegoro.

Lie, A. (2004). Cooperative Learning : Mempraktikkan Cooperative Learning di Ruang Ruang Kelas. Grasindo. Jakarta.

Mulyasa. 2011. Managemen Berbasis Sekolah, Konsep, Strategi dan Implementasi. Bandung : PT. Remaja Rosdakarya.

Mulyaningsih. 2012. Metode Penelitian Terapan Bidang Pendidikan.Yogyakarta : Alfabeta.

Putri, A.F.A., dkk. (2015). Penerapan Model Pembelajaran Problem Based Learning (PBL) Disertai Eksperimen Untuk Meningkatkan Interaksi Sosial Dan Prestasi Belajar Siswa Pada Materi Pokok Kelarutan Dan Hasil Kelarutan Di SMA Muhammadiyah 1 Karanganyar. Jurnal Pendidikan Kimia. Semarang ; UNS (Vol.4).

Suparmi,dkk. 2012. Pengaruh Metode Inquiri Terbimbing dan Proyek, Kreativitas, Serta Keterampilan Proses Sains Terhadap Prestasi Belajar Siswa. Jurnal : Jurnal Pendidikan Fisika, 9(1), hml. 28-34.

Slavin, R. (2008). Cooperative Learning Teori, Riset dan Praktik. Nusa Media.

Suyanti, R.D. (2010). Strategi Pembelajaran Kimia. Yogyakarta: Graha Ilmu. 